Kong. Res. J. 3(2) : 97-100, 2016

ISSN 2349-2694

Kongunadu Arts and Science College, Coimbatore.

\title{
MOSQUITOE'S LARVAL GROWTH WITH REFERENCE TO WATER PARAMETERS IN UKKADAM PERIYAKULAM LAKE- COIMBATORE, TAMILNADU, INDIA
}

\author{
Rajmohan. D*., R. Yamuna, K. Logankumar, M. Manimegalai and K. Sathish Kumar \\ PG and Research Department of Zoology, Kongunadu Arts and Science College, Coimbatore- 641029. \\ *E.mail: rajmohandevadass@gmail.com
}

\begin{abstract}
Mosquitoes lay eggs in a wide range of habitats with different physicochemical parameters. Ecological data, including physicochemical factors of oviposition sites, play an important role in integrated vector management. Those data help the managers to make the best decision in controlling the aquatic stages of vectors especially using source reduction. To study some physicochemical characteristics of larval habitat waters, an investigation was carried out in Ukkadam periyakullam lake Coimbatore. Water samples were collected during larval collection from three localities. The chemical parameters of water samples were analyzed based on $\mathrm{mg} / \mathrm{l}$ using standard methods. Water temperature $\left({ }^{\circ} \mathrm{C}\right.$ ), turbidity (NTU), total dissolved solids $(\mathrm{ppm})$, electrical conductivity $(\mu \mathrm{S} / \mathrm{cm})$, and acidity $(\mathrm{pH})$ were measured using digital testers. Thermotolerant coliforms of water samples were analyzed based on MPN/100ml. In total, 112 mosquito larvae were collected. There was no significant correlation between the abundance of larvae and the different physicochemical and microbial parameters. But fecal coliform was the major impacting factor in the study area.
\end{abstract}

Keywords: Mosquitoe, water parameters, Ukkadam Periyakulam lake.

\section{INTRODUCTION}

Mosquitoes are dipteran insects and blood sucking fly pests of man. Mosquitoes are surviving on earth since millions of years. They have always given tough time to men as important carriers of various diseases. People fight globally against mosquitoes and mosquito borne diseases. Malaria, Dengue, Filaria, Japanese encephalitis, West nile virus and Chikungunia are the major diseases spread globally by different mosquito. These diseases challenge the developed and developing countries of the world for irradicaton. Mosquitoes are very well recognized as vectors of protozoan, viruses and other pathogenic organisms, after the discoveries made by Sir Patrick Manson, Sir Ronald Ross and Sir Walter Reed. It is well known also that under the influence of environmental conditions a vector species may show changes in the seasonal distribution in the same area of dominance.

The increase in density of a vector species is very much dependent on climatological factors and water quality favorable for its breeding, and adult survival (Suresh chavathiya.2010). The basic aim of present study is to generate perfect baseline data about mosquito's larva in Ukkadam Lake

\section{MATERIALS AND METHODS}

\subsection{Study area}

The ukkadam periyakulam, the life line of many species, provides water for the essential requirements of life. However, over the years it has been subject to tremendous pressure due to untreated sewage and industrial effluents being dumped in to the river at numerous places and the residues of fish wastes servers as a good medium for the growth of mosquitoes larva. Hence that ukkadam periyakulam lake is selected for the study.

\subsection{Water sample collection}

In the whole lake three location where spotted for the study. And they were named as A, B, and C. Spot A is one end of the lake. It was polluted with the domestic wastes like vegetable wastes from around households; used plastic bottles, waste cloth, plastic papers, and many more wastes were dumped in the lake. Spot B is the other end of lake. It is very much polluted than the other end. This end is polluted with the animal wastes. That is waste parts of fish are directly put into the lake. The worst part is the wastes are put in a plastic carry bags and dumped into the lake. And also the septic sewage is passing through this end. Spot $\mathrm{C}$ is the center of the lake where no pollution is found. This spot was clear to see from outside. No physical pollutants were present. 
2.3. Methods of analysis for physicochemical parameters in water

Water samples were collected from A, B, and C. In a $1000 \mathrm{ml}$ container for testing its physicochemical parameters (I.O.Oyewole.,et al). The collected samples were then taken to SEEDS ENVIRO LAB, COIMBATORE. For testing water parameters like acidity, alkality, ammonia, $\mathrm{Ph}$, temperature, DO, total hardness, nitrate, organic nitrogen, phosphorus, free co2, calcium, magnesium, BOD, COD, total dissolved solids, and faecal coliform. However, a thermometer was used for measuring temperature on the field (Timb.B.M et.,al).

\subsection{Mosquitoes larval count}

The larval stages of mosquitoes were collected with a dipper. This method is called as dipping method. Dippers are the most commonly used tool. Which may vary in size and shape. The capacity of a few hundred milliliters to 1 liter. It is an inexpensive and easily used tool for collecting larvae (Dixon and brust 1972; lemenager et al.1986). In this study the larval stages of mosquitoes were collected by dipping which as done within 5 meter square area along the edges (Amerasinghe and Arivasena 1990).
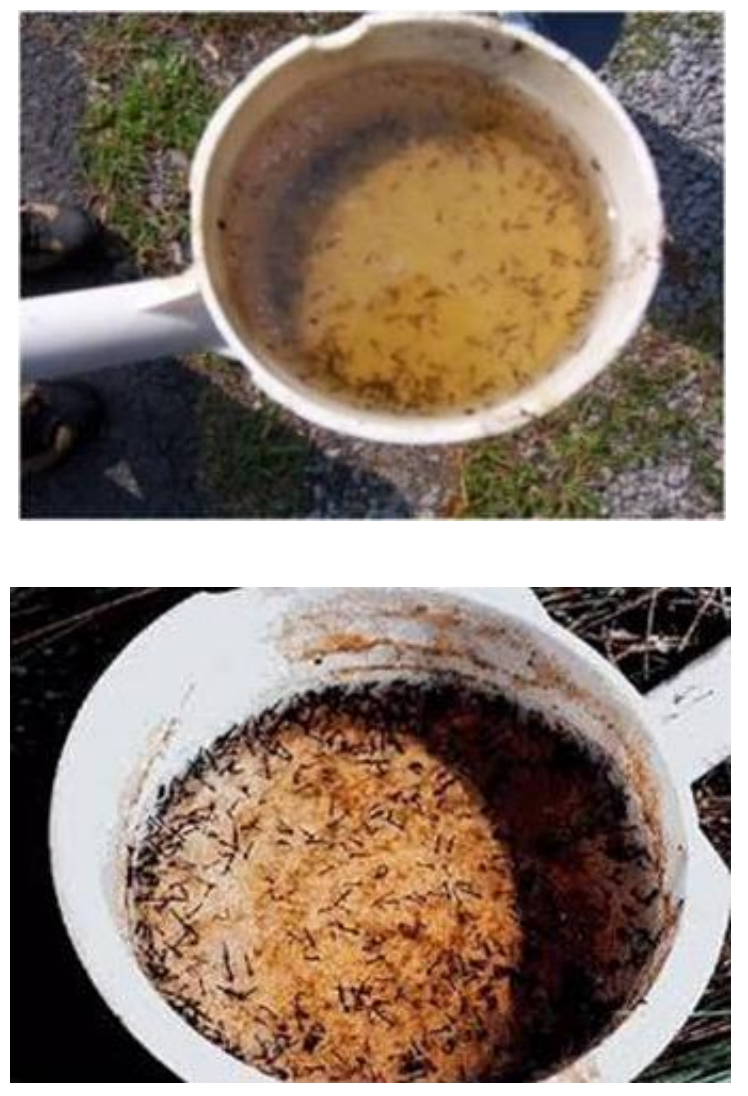
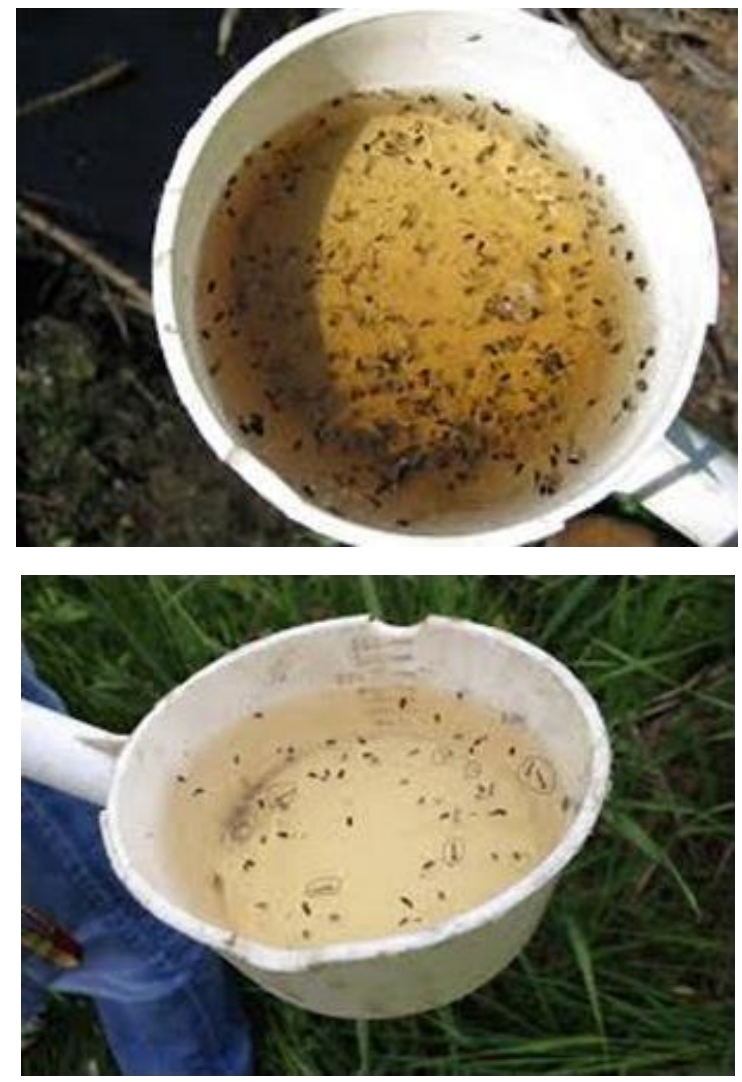

\section{RESULTS AND DISSCUSION}

To find out the suitable parameter for the mosquito larval growth. The water samples were tested for its physico-chemical properties (Table 1). The parameters of the three water samples were tested for homogeneity. And it was found that the samples were homogeny through correlation matrix (Table 3). Then proceeding to the correlation of each parameter with respect to larval count. This was done using a statistical tool. As a result it was found to be that temperature, total hardness, nitrate, organic nitrogen, phosphorus, megnesium, BOD, COD and fecal coliform were the major parameters which showed a positive correlation with respect to larval count (Table 3).

Further comparing the three samples A, B, and C. A and B were found to be abundance in larval count. This shows that the polluted water is a good source for the larval growth. And also the statistical result showed that fecal coli form is the major factor present in the lake which makes the water unfit for consuming. 
Table 1. Physicochemical characteristics of Ukkadam lake at the selected spots.

\begin{tabular}{llccc}
\hline S. No & \multicolumn{1}{c}{ Parameters } & Results \\
\cline { 3 - 5 } & & Sample A & Sample B & Sample C \\
\hline 1. & Acidity & $\mathrm{BDL}$ & $4.0 \mathrm{mg} / \mathrm{l}$ & $1.50 \mathrm{mg} / \mathrm{l}$ \\
2. & Alkalinity & $350.0 \mathrm{mg} / \mathrm{l}$ & $275.0 \mathrm{mg} / \mathrm{l}$ & $150.0 \mathrm{mg} / \mathrm{l}$ \\
3. & Ammonia & $\mathrm{BDL}$ & $\mathrm{BDL}$ & $\mathrm{BDL}$ \\
4. & $\mathrm{pH}$ & 8.26 & 7.48 & 7.18 \\
5. & Temperature & $27.5 \mathrm{C}$ & $27.7 \mathrm{C}$ & $27.4 \mathrm{C}$ \\
6. & Do & $5.80 \mathrm{mg} / \mathrm{l}$ & $5.40 \mathrm{mg} / \mathrm{l}$ & $6.10 \mathrm{mg} / \mathrm{l}$ \\
7. & Total hardness & $200.25 \mathrm{mg} / \mathrm{l}$ & $300.43 \mathrm{mg} / \mathrm{l}$ & $160.20 \mathrm{mg} / \mathrm{l}$ \\
8. & Nitrate & $17.43 \mathrm{mg} / \mathrm{l}$ & $22.56 \mathrm{mg} / \mathrm{l}$ & $7.42 \mathrm{mg} / \mathrm{l}$ \\
9. & Organic nitrogen & $1.0 \mathrm{mg} / \mathrm{l}$ & $1.0 \mathrm{mg} / \mathrm{l}$ & $0.02 \mathrm{mg} / \mathrm{l}$ \\
10. & Phosphorus & $14.0 \mathrm{mg} / \mathrm{l}$ & $16.56 \mathrm{mg} / \mathrm{l}$ & $5.60 \mathrm{mg} / \mathrm{l}$ \\
11. & Free CO & $\mathrm{BDL}$ & $\mathrm{BDL}$ & $\mathrm{BDL}$ \\
12. & Calcium & $24.04 \mathrm{mg} / \mathrm{l}$ & $40.08 \mathrm{mg} / \mathrm{l}$ & $24.04 \mathrm{mg} / \mathrm{l}$ \\
13. & Megnesium & $34.07 \mathrm{mg} / \mathrm{l}$ & $48.68 \mathrm{mg} / \mathrm{l}$ & $24.34 \mathrm{mg} / \mathrm{l}$ \\
14. & BOD & $40.0 \mathrm{mg} / \mathrm{l}$ & $42.0 \mathrm{mg} / \mathrm{l}$ & $12.0 \mathrm{mg} / \mathrm{l}$ \\
15. & COD & $110.0 \mathrm{mg} / \mathrm{l}$ & $170.0 \mathrm{mg} / \mathrm{l}$ & $70.0 \mathrm{mg} / \mathrm{l}$ \\
16. & Total dissolved solids & $703.0 \mathrm{mg} / \mathrm{l}$ & $505.60 \mathrm{mg} / \mathrm{l}$ & $300.70 \mathrm{mg} / \mathrm{l}$ \\
17. & Faecal coliform & $12 \mathrm{MPN} / 10 \mathrm{ml}$ & $14 \mathrm{MPL} / 10 \mathrm{ml}$ & $03 \mathrm{MPL} / 10 \mathrm{ml}$ \\
\hline
\end{tabular}

In the present study, 112 mosquito larvae were collected from the three spots A, B, and C. in the ukkadam periyakulam lake. Some physicochemical parameters of the sample in the study area showed significant differences among their localities. Like the total hardness $(300.43 \mathrm{mg} / \mathrm{l})$, nitrate $(22.56$ $\mathrm{mg} / \mathrm{l})$, nitrogen $(1.0 \mathrm{mg} / \mathrm{l})$, phosphorous (16.51 $\mathrm{mg} / \mathrm{l})$, magnesium (48.68 mg/l)BOD $42.0 \mathrm{mg} / \mathrm{l}$, COD $170.0 \mathrm{mg} / \mathrm{l}$, total dissolved solids $703.0 \mathrm{mg} / \mathrm{l}$ and the fecal coliform (140 MPL/100ml) (Fig. 1).

Table 2. The number of larvae counted at each spot.

\begin{tabular}{cccc}
\hline Dippings & Spot A & Spot B & Spot C \\
\hline 1 & 7 & 9 & 3 \\
2 & 8 & 7 & 0 \\
3 & 5 & 4 & 2 \\
4 & 3 & 9 & 0 \\
5 & 6 & 7 & 0 \\
6 & 2 & 4 & 1 \\
7 & 4 & 6 & 0 \\
8 & 3 & 5 & 2 \\
9 & 5 & 4 & 1 \\
10 & 2 & 3 & 0 \\
\hline
\end{tabular}

Total number of larva counted in $\operatorname{spot} A=45$, spot $B=58$ and $\operatorname{spot} C=9$

Total number of larva counted in the lake $=112$

Khamala (1971) found that dissolved solids,ph,total nitrogen did not show any significant correlation with the density of some mosquitoes larval species. The same was found in the present study. Hanafi-bojd et al (2012). Noted the temperature, ph, total hardness, and dry residue of larval habitat, to that of larval density did not correlate. Both ghanbari et al. (2005). And hanafibojd et al. 2012). Mentioned the habitats in general. None of them provided the exact values of physico chemical features for each species. Piyaratne MK, Amerasinhe FP,Amerasinghe $\mathrm{PH}$, konradsen $\mathrm{F}$ (2005). Found a positive correlation of some Anopheles species abundance only to temperature and calcium. Surendran and ramasamy (2003). Observed few anopheles species abundance to dissolved oxygen. Ibrahim AA,El-Monairy OM, ElSayed, (2011).found that the temperature ,ammonia,and nitrogen are the best predictor for larval density. However no correlation was found between larval density, PH, and dissolved oxygen.

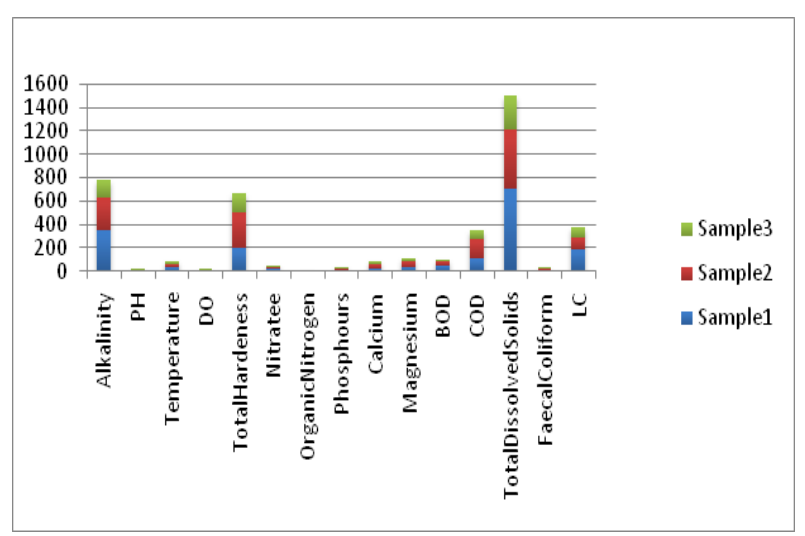

Fig. 1. Statistical diagram showing the relationship between the parameters and larval count of sample A, B and C. 
Table 3. Correlation between the parameters of the three water samples.

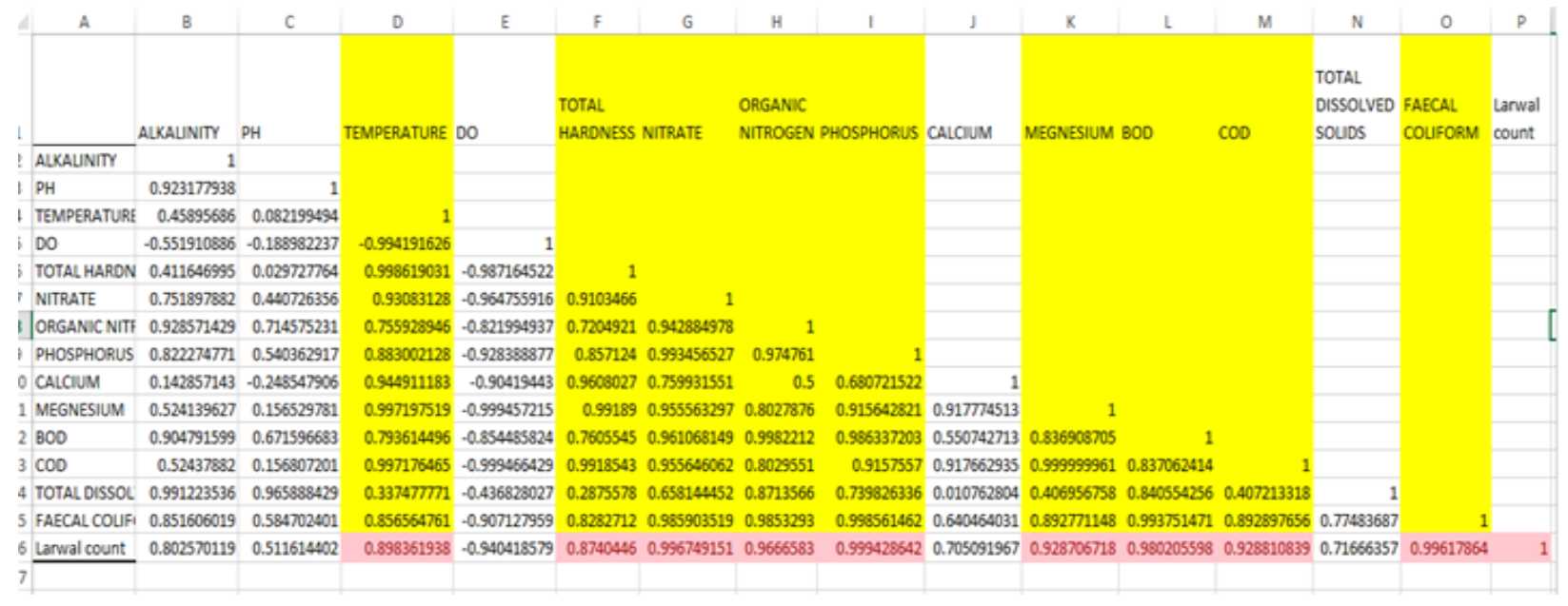

Among the physicochemical parameters and based on the current investigation,the fecal coliform is the major impacting parameter for larval abundance.As it is obvious, some available data are contradictory and there is not enough information about physicochemical parameters of larval habitats for many mosquitoes species.in addition to the biological differences of different species, the same species has a range of tolerance and sometimes show different correlation with physicochemical parameters.

\section{REFERENCES}

Chattahoochee, (2003). Riverway Project.

Dixon and Burst, (1972). Mosquito ecology. Field sampling methods.

Ghanbari, M.R., A. Rakhsh khorshid, M. Salehi and A. Hassanzehi, (2005). The study of physical and chemical factors affecting breeding places of Anopheles in iran-shahr. Tabib-e-shargh, J. Zahedan Univ. Med. Sci. 7:221-227.

Hanafi-Bojd, A.A., H. Vatandoost, M.A. Oshaghi, Z. Charrahy, A.A. Haghdoost, M.M. Sed-aghat, F. Abedi, M. Soltani and A. Raeisi, (2012). Larval habitats and biodiver- site of anopheline mosquitoes in a malarious area of southern iran. J. Vector Borne Dis. 49:91-100.

Ibrahim, A.A., O.M. El-Monairy, Y.A. El-Sayed and M.M. Baz, (2011). Mosquito breeding sources in Qalyubiya Governorate. Egypt. Egypt Acad. J. Biol. Sci. 3:25- 39.

Khamala, P.M.C., (1971). The biting flies of Kano plains, Kenya: Part II. Larval habitats of common mosquito species (Diptera: Culicidae). Bull. Entomol. Res. 61:299- 307.

Mian ls Lovett, J. and M.S. Dhillon, (2009). Effect of effluent-treated water on mosquito development in simulated ponds at the Prado Wetlands of southern California. JAM Mosq. Control Assoc. 25(3): 347-355.

Navarro, D.M.A.F, P.E.S. de Oliveira, R.P.J. Potting, A.C. Brito, S.J.F. Fital and A.E.G. Sant'Ana, (2003). The potential attractant or repellent effects of different water types on oviposition in Aedes aegypti L. (Dipt., Culicidae). J. Appl. Entomol. 127:46-50.

Oyewole, I.O., O.O. Momoh, G.N. Anyasor, A.A. Ogunnowo, C.A. Ibidapo, O.A. Oduola, J.B. Obansa and T.S. Awolola, (2009). Physico-chemical characteristics of Anopheles breeding sites: Impact on fecundity and progeny development. Afr. J. Environ. Sci. Technol. 3(12):447-452.

Paaijmans, K.P., W. Takken, A.K. Githeko, A.F. Jacobs, (2008). The effect of water turbidity on the near surface water temperature of larval habitats of the malaria mosquito Anopheles gambiae. Int. J. Biometeorol. 52(8):747-53.

Piyaratne, M.K., F.P. Amerasinhe, P.H. Amerasinghe and F. Konradsen, (2005). Physicochemical characteristics of Anopheles culicifacies and Anopheles varuna breeding water in a dry zone stream in Sri Lanka. J. Vector Borne Dis. 42:61- 67.

Stephanie sue schelble, (2014). Effects of water parameters on cointainer mosquito (dipteral: culicidae) oviposition and performance. Master's theses.

Surendran, S.N. and R. Ramasamy, (2005). Some characteristics of the larval breeding sites of Anopheles culicifacies species B and E in Sri Lanka. J. Vector Borne Dis. 42:39- 44.

Timub, B.M, B.K. Adu and K. Obiri-Danso, (2012). Physico-chemical assessment of mosquito breeding sites from selected mining communities at the obuasi municipality in Ghana. J. Environ. Earth Sci. 2(10):12-20. 